\title{
THE INFLUENCE OF APPLIED STABILIZATION METHOD ON THE CRYSTALLINE STABILITY OF YOUNG WHITE WINES
}

\author{
Ecaterina Covaci* $^{*}$, Gheorghe Duca ${ }^{\mathrm{b}}$, Rodica Sturza ${ }^{\mathrm{c}}$ \\ ${ }^{a}$ Institute of Chemistry, Academy of Sciences of Moldova, 3, Academiei str., Chisinau, MD-2028, Republic of Moldova \\ ${ }^{\mathrm{b}}$ Academy of Sciences of Moldova, 1, Stefan cel Mare Blvd., Chisinau, MD-2001, Republic of Moldova \\ ${ }^{c}$ Technical University of Moldova, 168, Stefan cel Mare Blvd., Chisinau, MD-2004, Republic of Moldova \\ *e-mail: covaci_ecaterina@yahoo.com
}

\begin{abstract}
Crystalline precipitate which occurs due to the presence of tartaric salts is frequently encountered in young wines in form of white-dirty lamellar crystals at the bottom of tank. The aim of the study was to prevent the tartaric crystal growth in young wine blend Bianca/Sauvignon by implementing various schemes and procedures. The recommendations of optimum regime, based on experimental results, include: the use of enzyme preparations, hot suspension of oversaturated bentonite in potassium hydrogen tartrate (KHT), cooled wine, maintained until stabilization and filtration.
\end{abstract}

Key words: young white wine, crystalline stabilization, suspension of bentonite, conductivity.

\section{Introduction}

One of the basic parameters of the quality of wines is the crystalline stability which is determined by the physicalchemical equilibrium state of tartaric acid salts present in wine. Tartaric acid, also known as dihydroxysuccinic acid can be found in wine in two forms: free and bounded [1]. The ionic species of tartaric salts which exist at physicalchemical equilibrium are unstable and more likely they will react with other compounds present in wine, such as: colored compounds, proteins, polymers, pectins, glucans, polysaccharides, etc. This interaction causes the formation of crystalline precipitate $[2,3]$.

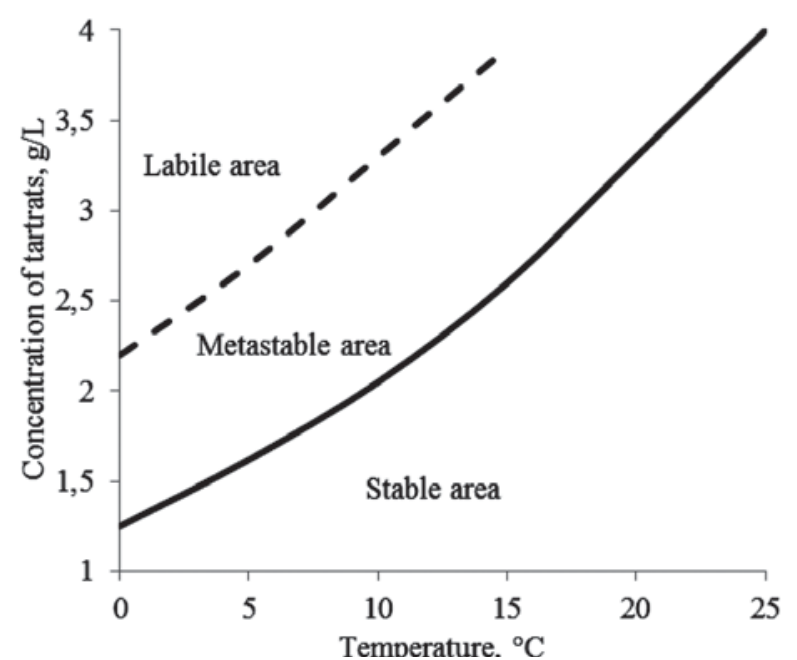

a)

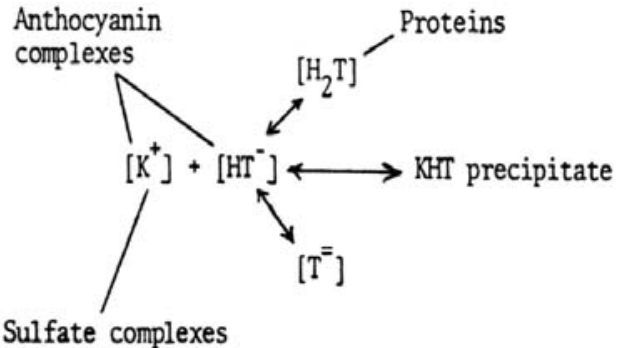

b)

Figure 1. Overview of the process: a) changes in the steady state of tartrate as a function of temperature [2]; b) possible interactions of wine tartaric acid forms with the components of wine [4].

The interaction of tartaric species with other compounds present in wine explains the process of tartrate crystals growth, the natural precipitation and its slow stabilization.

After alcoholic fermentation, the content of tartaric salts in wine is higher than $3 \mathrm{~g} / \mathrm{L}$, as a result wine becomes an oversaturated solution of tartaric salts, which at the keeping/treating temperature are susceptible to spontaneous crystallization (instability area, Figure 1) [1,5]. During the storage of wine the content of tartaric salt diminishes slowly. The intensity of tartrate crystals precipitation and crystals size are dependent on temperature, composition (alcohol, tartaric acid, $\mathrm{pH}$, potassium, calcium, etc.), the presence of nucleation and inhibition centers and the volume of storage vessels [6].

Changes of physical-chemical steady states of tartaric salts are mostly generated by temperature changes; this induces the system into a certain degree of stability or instability. The stability of young wines may be improved by implementing the cold treatment step in the winemaking process [6,7]. The process consists in reduction of the solubility of tartaric salts of wine until the formation of the oversaturated solution that initiates and/or grows tartaric crystals which 
are then removed without subsequent re-solubilization (filtration at the same temperature). The difficulty of this method consists in performing of two consecutive processes: creation of micro crystals (initiation) and their subsequent growth. The creation stage (initiation) of micro crystals is slow by the formation of a new phase (solid) in the oversaturated solution which is followed by their growth, achieved by creating and maintaining the necessary conditions for their growth $[7,8]$.

Various methods for stabilizing of young wines are discussed in the literature [6-8]. These methods include the traditional stabilization by cooling or adding of potassium salts, bentonite suspension and ethanol, followed by cooling treatment at different regimes, homogenized and stored in the cold until the stabilization.

\section{Experimental}

Samples of white wine which was stabilized through various treatment schemes, stabilization materials and thermal regimes were subjected to our study. Physical-chemical and chromatic parameters of wine samples were determined using experimental procedures described elsewhere $[9,10]$.

The experimental wine samples no. 2, 3 and 4 were subjected to an enzymatic treatment using Enzym'Vander (Bordeaux, France) at a dose of $0.5 \mathrm{~g} / \mathrm{L}$, for a period of 24 hours. During all the testing period the samples were maintained at temperature of $-5^{\circ} \mathrm{C}$. To prevent the re-solubilization of deposited crystals, after stabilization step, samples were filtered at the temperature of treatment.

The hot suspension of oversaturated bentonite in potassium hydrogen tartrate (THK) was prepared as follows: in the $10 \%$ Solub bentonite solution $75 \mathrm{~g} / \mathrm{L}$ potassium hydrogen tartrate was used. This suspension was heated and maintained at the temperature of $85-95^{\circ} \mathrm{C}$ until the introduction of it in the cooled wine. The used hot suspension of bentonite doses in THK in the preventive cooled wine to $-5^{\circ} \mathrm{C}$ were 1.5 and $1.75 \mathrm{~g} / \mathrm{L}$. The crystalline stability of wines has been evaluated by methods described in the literature $[6,10]$. The conditions of technological procedures applied for wine stabilization are presented in Table 1.

Table 1.

Technological procedures applied for wine stabilization.

\begin{tabular}{|c|l|}
\hline $\begin{array}{c}\text { No. } \\
\text { sample }\end{array}$ & \multicolumn{1}{|c|}{ Wine stabilization schemes } \\
\hline $\begin{array}{c}\text { Control } \\
\text { sample }\end{array}$ & $\begin{array}{l}\text { Wine treated by the traditional method with bentonite, } 2.5 \mathrm{~g} / \mathrm{L} \text {, filtered, cooled and kept cool throughout } \\
\text { the stabilization. }\end{array}$ \\
\hline 1 & $\begin{array}{l}\text { Wine treated with the oversaturated hot bentonite suspension in KHT at a dose of } 2 \mathrm{~g} / \mathrm{L} \text { and kept cold } \\
\text { throughout the stabilization. }\end{array}$ \\
\hline 2 & $\begin{array}{l}\text { Wine treated with pectolytic enzyme product, bentonite at a dose of } 1.75 \mathrm{~g} / \mathrm{L} \text { and kept cool throughout the } \\
\text { stabilization. }\end{array}$ \\
\hline 3 & $\begin{array}{l}\text { Wine treated with the pectolytic enzyme product, then oversaturated hot bentonite suspension in KHT at } \\
\text { a dose of } 1.5 \mathrm{~g} / \mathrm{L} \text { in cooled wine and kept cool throughout the stabilization. }\end{array}$ \\
\hline 4 & $\begin{array}{l}\text { Wine treated with the pectolytic enzyme product, then oversaturated hot bentonite suspension in KHT at } \\
\text { a dose of } 1.75 \mathrm{~g} / \mathrm{L} \text { in cooled wine and kept cool throughout the stabilization. }\end{array}$ \\
\hline
\end{tabular}

The treated wine samples were tested via three tests of crystalline stability control - Mini Contact, the saturation temperature and alcohol content. The monitored parameter of the samples was conductive capacity of wine which is mainly determined by the excess of potassium hydrogen tartrate (KHT) [8]. The values of these parameters decrease with the increase of the tartaric crystal and they were determined by conductometer ECITDS - Hanna (characteristics are presented in Table 2).

The Mini Contact test consists in determination of the conductivity of wine samples, this is followed by cooling till $+5^{\circ} \mathrm{C}$ and administration of THK; pretreated samples are kept at this temperature for 2 hours with a periodic mixing. Then the final conductivity is measured without agitation or preventive wine heating. According to the requirements of stability for stable wines the difference between the determined conductivities shall not exceed $50 \mu \mathrm{S} / \mathrm{cm}$; otherwise, the wine is prone to the tartaric precipitation. Under the determination of the conductivity of wine at temperatures higher than of $18^{\circ} \mathrm{C}$ the saturation temperature is calculated using following mathematical expression:

$$
T_{\text {sat }}=T-\frac{L F_{2}-L F_{1}}{33},{ }^{\circ} \mathrm{C}
$$

where: $\mathrm{T}$ - temperature of the sample, ${ }^{\circ} \mathrm{C}$

$\mathrm{LF}_{2}$ - conductivity after the usage of $5 \mathrm{~g}$ of $\mathrm{KHT}$ and the homogenization, $\mu \mathrm{S} / \mathrm{cm}$;

$\mathrm{LF}_{1}$ - initial conductivity of the sample, $\mu \mathrm{S} / \mathrm{cm}$. 
According to the requirements of stability of young white wines, the value of the saturation temperature should not exceed $10 \div 12^{\circ} \mathrm{C}$. At higher values (ranging in the interval $12 \div 16^{\circ} \mathrm{C}$ ), it is recommended the use of mesotartaric acid or carboxymethyl cellulose acting as inhibitors of the tartaric crystallization process.

Table 2.

Hanna conductometer parameters.

\begin{tabular}{|c|c|c|}
\hline Photo overview & Specific parameters & Parameters value \\
\hline \multirow{9}{*}{$\frac{F}{E}$} & CE range & $0 \div 3999 \mu \mathrm{S} / \mathrm{cm} \pm 1 \mu \mathrm{S} / \mathrm{cm}$ \\
\hline & TDS range & $0 \div 2000 \mathrm{ppm} \pm 1 \mathrm{ppm}$ \\
\hline & Temperature range & $0 \div 60^{\circ} \mathrm{C} \pm 0.1^{\circ} \mathrm{C}$ \\
\hline & CE and TDS accuracy & $\pm 2 \%$ F.S. \\
\hline & Temperature accuracy & $\pm 0.5^{\circ} \mathrm{C}$ \\
\hline & Adjustable TDS conversion factor & $0.45 \div 1.00$ \\
\hline & Automatic temperature compensation & $0.0 \div 2.4 \% /{ }^{\circ} \mathrm{C}$ \\
\hline & $\begin{array}{l}\text { Working conditions } \\
\text { temperature range } \\
\text { UR max } \\
\text { CAE }\end{array}$ & $\begin{array}{l}0 \text { to } 50{ }^{\circ} \mathrm{C} \\
100 \% \\
\text { Battery type } 4 \times 1.5 \mathrm{~V} \text {, system BEPS }\end{array}$ \\
\hline & The size and the weight & $163 \times 40 \times 26 \mathrm{~mm}, 100 \mathrm{~g}$ \\
\hline
\end{tabular}

\section{Results and discussion}

The physical-chemical assessment results and those of crystalline stability are dependent on applied stability process. Values obtained at the initial stage are presented in Table 3, and their evolution in dynamics was monitored. During treatment procedures, significant changes of wine parameters were registered for: sulfur dioxide $\left(\mathrm{SO}_{2}\right)$, titratable acidity, chromatic parameters, saturation temperature, content of mineral compounds (potassium, calcium, tartaric acid, etc.) and organoleptic parameters. The value of the content of sulfur dioxide was reduced by $20 \div 45 \%$, the titratable acidity increased by 0.35 units of control samples and the others increased insignificantly. We have registered changes for the chromatic parameter which represents the color intensity (absorbance registered at $420 \mathrm{~nm}$ ). It has decreased to the interval $4 \div 15 \%$ in dynamics being induced by the decrease of protein content in wine samples (see Figure 2).

Values of concentration and solubility product of the original wine were calculated using the established parameters: ionic strength, activity coefficient, exponents of acidity, etc (see Table 3 ). The value of concentration product of $\operatorname{KHT}\left(\mathrm{Pc}=152^{*} 10^{-6}\right)$ was seven times higher than the solubility product of wine $\left(\mathrm{S}_{\mathrm{P}}=21.8^{*} 10^{-6}\right)$.

Table 3.

Physical-chemical and organoleptic parameters of young wine blend „Bianca/Sauvignon”.

\begin{tabular}{|c|c|c|}
\hline $\begin{array}{l}\text { No. } \\
\text { crt. }\end{array}$ & Parameters & Values \\
\hline 1 & VAT, $\%$ vol & $13.0 \pm 0.1$ \\
\hline 2 & Residual sugar, g/L & $3.33 \pm 0.11$ \\
\hline 3 & Saturation temperature of $\mathrm{T}_{\mathrm{sat} \text { KтH }},{ }^{\circ} \mathrm{C}$ & $17 \pm 0.001$ \\
\hline 4 & Saturation temperature of $\mathrm{T}_{\mathrm{satCa}}{ }^{\circ}{ }^{\circ} \mathrm{C}$ & $8 \pm 0.001$ \\
\hline 5 & Titratable acidity, g/L & $5.82 \pm 0.04$ \\
\hline 6 & Volatile acidity, g/L & $0.73 \pm 0.04$ \\
\hline 7 & $\mathrm{pH}$ & $3.53 \pm 0.01$ \\
\hline 8 & Content of Iron, $\mathrm{mg} / \mathrm{L}$ & $0.390 \pm 0.016$ \\
\hline 9 & Content of sulfur dioxide (free/total), mg/L & $70 / 90.8 \pm 1$ \\
\hline 10 & Content of potassium, $\mathrm{g} / \mathrm{L}$ & $0.520 \pm 0.01$ \\
\hline 11 & Content of tartaric acid, $\mathrm{g} / \mathrm{L}$ & $2.711 \pm 0.001$ \\
\hline 12 & Contents of excess potassium hydrogen tartrate, $\mathrm{mol} / \mathrm{L}$ & $0.0062 \pm 0.001$ \\
\hline 13 & Type of shown instability & Crystalline and colloidal instability \\
\hline 14 & Organoleptic characteristics & $\begin{array}{l}\text { Opal wine, yellow with greenish shades. } \\
\text { Fine flavor, clean, but dark. Stodgy taste, } \\
\text { disharmonious and a slight acidity. }\end{array}$ \\
\hline
\end{tabular}




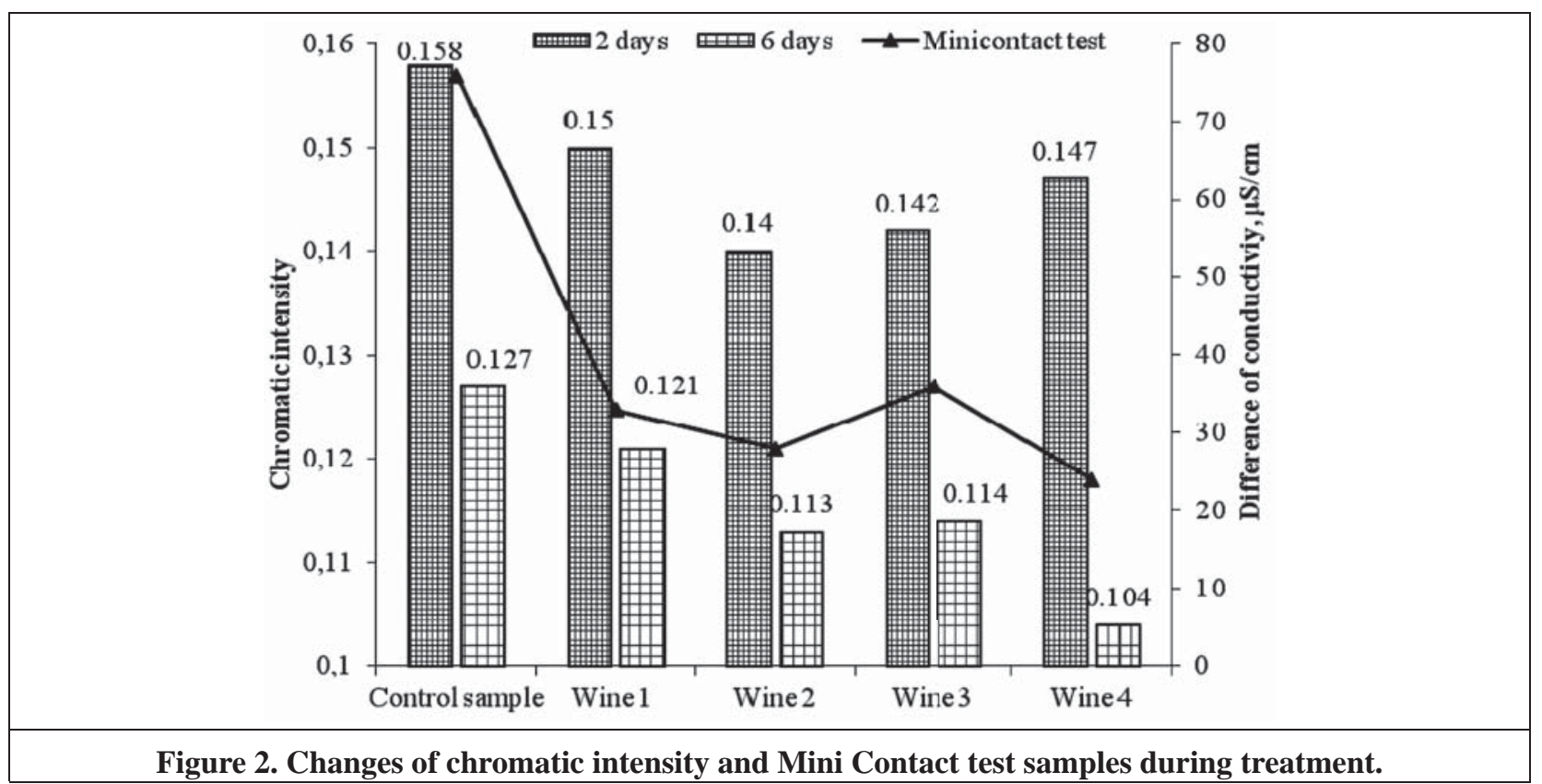

During the treatment conditions (temperature $-5^{\circ} \mathrm{C}$, concentrations of tartaric acid $0.018 \mathrm{~mol} / \mathrm{L}$ and of potassium $0.013 \mathrm{~mol} / \mathrm{L}$ ), young wine is presented to be oversaturated in potassium hydrogen tartrate. The excess quantity of potassium hydrogen tartarate is $0.0062 \mathrm{~mol} / \mathrm{L}$ which causes tartaric precipitation in a short time.

The crystalline stabilization process of wine is difficult and lengthy and its effectiveness is influenced by many factors, both compositional ones as well as related to the physical-chemical properties of the wine and thermodynamic regimes applied to cooling and keeping. The effectiveness of the stabilization of samples was studied in dynamics by determination of the electro-conductivity and calculation of the saturation temperature. This parameter describes the long-term stability wine and the probability of crystalline disorders triggering in the long run. The values of these parameters decrease as tartaric crystals increase and the saturation temperature calculation was performed by the expression described in the previous section.

The maximum period of control sample has reached 10 days and a saturation temperature of $11^{\circ} \mathrm{C}$, which was determined by the nucleation of slow and lasting crystallization. The experimental samples no. 3 and 4 have described a stabilization period of 4 and 6 days, illustrated in Figure 3. The stabilized wine samples were tested by the three tests of crystalline stability control and presented as stable in the calculations.

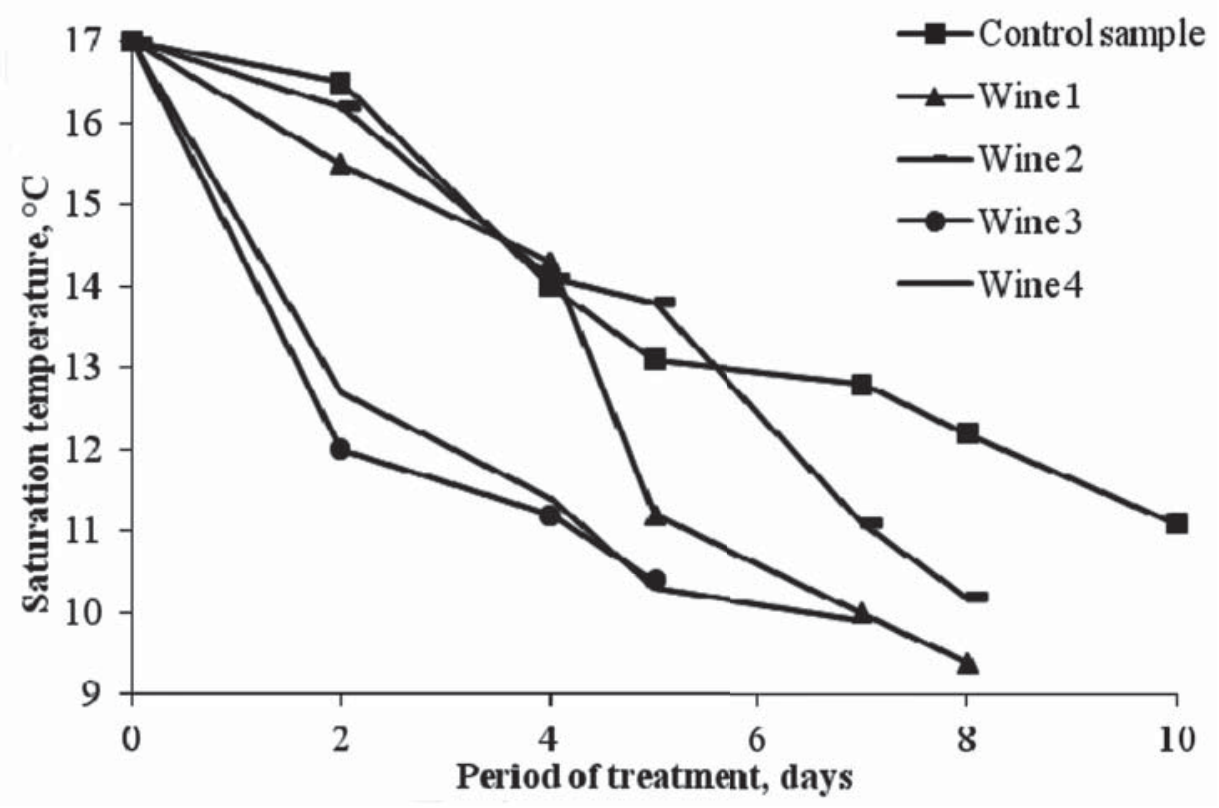

Figure 3. The dynamics of the saturation temperature. 
Stabilization of wine samples has conducted to an improvement of their organoleptic characteristics, spreading the flavor, the persistence of flavor and color for this type of wine. Samples no. 3 and 4 were appreciated by the tasters with a maximum score. These changes were induced as a result of the enzymatic treatment combined with bentonite hot oversaturated suspension in KHT.

\section{Conclusions}

As a result of our study it has been established that the use of the bentonite hot oversaturated suspension in potassium hydrogen tartarate provides the best conditions for initiation and growth of tartaric crystals. The wine stability testing by determining the saturation temperature and the Mini Contact test are the important information parameters that characterize its nativity.

Summing, we recommend an optimum regime of crystalline stabilization of young white wines which includes steps such as: the use of enzymatic treatment, hot suspension of oversaturated bentonite in potassium hydrogen tartarate at a concentration of $1.5 \div 1.75 \mathrm{~g} / \mathrm{L}$ in cooled wine to $-5^{\circ} \mathrm{C}$, maintenance at this temperature until stabilization and filtration.

\section{References}

[1] Cotea, V.D.; Zanoaga, C.; Cotea, V.V. Tratat de oenochimie. Vol. II, Bucuresti: Ed. Academiei Romane, 2009, $750 \mathrm{p}$.

[2] Vallee, D.; Bagard, A.; Bloy, C. and Bourde, L. Appreciation de la stabilite tartrique des vins par la temperature de saturation - Influence du facteur temps sur la stabilite (duree de stockage). Rev. Fr. Oenol., 1990, 126, pp. 51-61.

[3] Usseglio-Tomasset, L.; Ubigli, M. et Barbero, L. L'etat de sursaturation des vins en tartrate acide de potassium. Bulletin O.I.V., 1992, Nr. 739, pp. 703-719.

[4] Zoecklein, B. A review of potassium bitartrate stabilization of wines. Virginia Cooperative Service, 1988, Nr. 463-013, pp. 1-14.

[5] Enache, G.; Tofan, I. The influence of low temperature on stabilization process of wine. Journal of Agroalimentary Processes and Technologies, 2007, Vol. 13, No.2, pp.319-324.

[6] Taran, N.; Zinchenko, V. Sovremennye tehnologii stabilizacii vin. Chisinau: NAM, 2006, 240 p.

[7] Prida, I.; Prida, A.; Ialovaia, A. Procedeu de tratare a vinurilor materie prima cu frig. B.I. MD 2010 0001 , Nr. 4057 $\operatorname{din}$ 31.07.2010.

[8] Prida, I.; Prida, A.; Ialovaia, A. s.a. Procedeu de stabilizare a vinului fata de tulburarile cristaline. B.I. MD 2012 015, Nr. 637 din 31.05.2013.

[9] Gerzhikovoj, V. Metody tehnohimicheskogo kontrolja v vinodelii. Simferopol': Tavrida, 2009, 304 p.

[10] Reguli generale privind fabricarea vinurilor de struguri naturale, RG MD 67-40582515-05:2010. 